\title{
Influence of Cation Transporters (OCTs and MATEs) on the Renal and Hepatobiliary Disposition of [ " C]Metoclopramide in Mice
}

\author{
Irene Hernández-Lozano' • Severin Mairinger ${ }^{2} \cdot$ Michael Sauberer $^{2} \cdot$ Johann Stanek $^{2}$. \\ Thomas Filip ${ }^{2}$. Thomas Wanek ${ }^{2}$ - Giuliano Ciarimboli ${ }^{3}$ - Nicolas Tournier ${ }^{4}$ - Oliver Langer 1,2,5 (D)
}

Received: 4 September 2020 / Accepted: 4 November 2020 / Published online: 8 February 2021

(C) The Author(s) 2021

\section{ABSTRACT}

Purpose To investigate the role of cation transporters (OCTs, MATEs) in the renal and hepatic disposition of the radiolabeled antiemetic drug $\left[{ }^{11} \mathrm{C}\right]$ metoclopramide in mice with PET.

Methods PET was performed in wild-type mice after administration of an intravenous microdose $(<1 \mu \mathrm{g})$ of $\left[{ }^{1} \mathrm{C}\right]$ metoclopramide without and with co-administration of either unlabeled metoclopramide (5 or $10 \mathrm{mg} / \mathrm{kg}$ ) or the prototypical cation transporter inhibitors cimetidine $(150 \mathrm{mg} / \mathrm{kg}$ ) or sulpiride (25 mg/kg). $\left[{ }^{1} \mathrm{C}\right]$ Metoclopramide PET was also performed in wild-type and S/C22al/2(-/-) mice. Radiolabeled metabolites were measured at 15 min after radiotracer injection and PET data were corrected for radiolabeled metabolites.

Results $\left[{ }^{11} \mathrm{C}\right.$ ] Metoclopramide was highly metabolized and $\left[{ }^{11} \mathrm{C}\right]$ metoclopramide-derived radioactivity was excreted into the urine. The different investigated treatments decreased $(\sim 2.5$-fold $)$ the uptake of $\left[{ }^{11} \mathrm{C}\right]$ metoclopramide from plasma into the kidney and liver, inhibited metabolism and decreased (up to 3.8-fold) urinary excretion, which resulted in increased plasma concentrations of $\left[{ }^{1} \mathrm{C}\right]$ metoclopramide. Kidney and

Oliver Langer

oliver.langer@meduniwien.ac.at

Department of Clinical Pharmacology, Medical University of Vienna, A- 1090 Vienna, Austria

2 Preclinical Molecular Imaging, AITAustrian Institute of Technology GmbH, Seibersdorf, Austria

3 Medicine Clinic D. Experimental Nephrology, University Hospital Münster, Münster, Germany

4 Laboratoire d'Imagerie Biomédicale Multimodale (BioMaps), CEA, CNRS, Inserm, Service Hospitalier Frédéric Joliot, Université Paris-Saclay, Orsay, France

5 Department of Biomedical Imaging and Image-guided Therapy, Division of Nuclear Medicine, Medical University of Vienna, Vienna, Austria liver uptake were moderately $(\sim 1.3$-fold $)$ reduced in Slc22al/ $2^{(-/-)}$mice.

Conclusions Our results suggest a contribution of OCT1/2 to the kidney and liver uptake and of MATEs to the urinary excretion of $\left[{ }^{1} \mathrm{C}\right]$ metoclopramide in mice. Cation transporters may contribute, next to variability in the activity of metabolizing enzymes, to variability in metoclopramide pharmacokinetics and side effects.

KEY WORDS [ ' ' C]metoclopramide · CYP2D6 - multidrug and toxin extrusion proteins (MATEs) · organic cation transporters $(\mathrm{OCT}) \cdot$ positron emission tomography (PET)

\section{ABBREVIATIONS}

AUC Area under the concentration-time curve

i.v. Intravenous

MATEs Multidrug and toxin extrusion proteins

OCTs Organic cation transporters

P-gp P-glycoprotein

PET Positron emission tomography

TLC Thin-layer chromatography

\section{INTRODUCTION}

Metoclopramide is a gastroprokinetic and antiemetic drug commonly prescribed for the treatment and prevention of various gastrointestinal disorders such as gastroparesis, esophageal reflux, dyspepsia, or chemotherapy-related nausea (1). In 2009, the FDA issued a black box warning regarding the use of metoclopramide because of its side effects in the central nervous system (2). Central side effects associated with longterm treatment with metoclopramide include tremors and Parkinson-like symptoms, which are caused by blockade of 
dopamine $\mathrm{D}_{2}$ receptors in the basal ganglia (3). Moreover, it has been reported that after prolonged or high-dose treatment with metoclopramide patients are at higher risk of developing tardive dyskinesia, a potentially irreversible serious movement disorder $(4,5)$. In addition, metoclopramide is associated with highly variable clinical response (6).

After oral dosing, metoclopramide undergoes significant firstpass metabolism in the liver, resulting in highly variable oral bioavailability. Approximately $20 \%$ of a single oral or intravenous (i.v.) dose of metoclopramide is excreted unchanged in urine, and up to $60 \%$ in the form of metabolites (7-9). One major metabolic pathway of metoclopramide is oxidation by CYP2D6 in the liver followed by conjugation $(10,11)$. An $\mathcal{N}$ O-glucuronide has been identified as the major metoclopramide metabolite in human urine and plasma $(12,13)$. Previous studies have provided evidence for non-linear pharmacokinetics of metoclopramide in rats and humans, suggesting a role of saturable mechanisms in its clearance $(9,14-16)$. Another study reported dose dependency in the uptake rate constant of metoclopramide from plasma into the rat liver, pointing to the involvement of hepatic uptake transporters in the metabolic clearance of metoclopramide (17).

At physiological $\mathrm{pH}$, more than $99 \%$ of metoclopramide is in protonated form, which suggests that cation transporters may contribute to its passage over biological membranes $(\mathrm{p} K \mathrm{a}=$ $9.71, \log D$ octanol/water $\mathrm{pH} 7.4=0.46)(18)$. Metoclopramide is a weak substrate of human and murine $\mathrm{P}$ glycoprotein (P-gp/ABCB1) $(19,20)$, which was shown to mediate in vivo its elimination from the brain in rats, non-human primates and humans (21-23). In vitro studies showed that metoclopramide is also a substrate of human organic cation transporters (OCTs) 1 and 2 (OCT1/SLC22A1 and OCT2/SLC22A2) (24). In humans, OCT1 is predominantly expressed in the basolateral (blood-facing) membrane of hepatocytes and OCT2 in the basolateral membrane of kidney proximal tubule cells, while in mice both OCT1 and OCT2 are expressed in the kidneys (25-27). Due to the functional coupling between OCTs and multidrug and toxic extrusion (MATE) proteins in the excretion of organic cations, it may be hypothesized that metoclopramide is also a substrate of MATE1/SLC47A1 and MATE2-K/SLC47A2. Both MATE1 and MATE2-K are expressed in the luminal (urine-facing) membrane of kidney proximal tubule cells $(25,28)$. The genes encoding for OCT1/ 2 and MATEs are highly polymorphic, which may lead to variability in the pharmacokinetics and clinical response to their substrate drugs (29).

Positron emission tomography (PET) allows monitoring of the tissue concentrations of radiolabeled drugs and has been used to assess the impact of transporters on drug distribution and excretion (30). [ ${ }^{11} \mathrm{C}$ ]Metoclopramide has been developed as a PET radiotracer to study $\mathrm{P}$-gp activity at the blood-brain barrier (21-23). The aim of this study was to assess by means of PET imaging with $\left[{ }^{11} \mathrm{C}\right]$ metoclopramide in mice the role of cation transporters (OCTs, MATEs) as possible factors accounting for variability in metoclopramide disposition. To this end, we assessed the dose dependency of $\left[{ }^{11} \mathrm{C}\right]$ metoclopramide disposition and the effect of administration of prototypical cation transporter inhibitors. In addition, to further assess the role of OCTs in the disposition of $\left[{ }^{11} \mathrm{C}\right]$ metoclopramide, Slc22a1/2 $2^{(-/-)}$mice were investigated.

\section{MATERIALS AND METHODS}

\section{Chemicals}

Unless otherwise stated, all chemicals were purchased from Sigma-Aldrich (Schnelldorf, Germany) or Merck (Darmstadt, Germany). I.v. injection solutions of metoclopramide (Paspertin ${ }^{\circledR}, 10 \mathrm{mg} / 2 \mathrm{~mL}$, Mylan Österreich $\mathrm{GmbH}$, Vienna, Austria), cimetidine $(200 \mathrm{mg} / 2 \mathrm{~mL}$, ratiopharm GmbH, Ulm, Germany) and sulpiride (Dogmatil®, $100 \mathrm{mg} / 2 \mathrm{~mL}$, Sanofi-Aventis Deutschland GmbH, Frankfurt am Main, Germany $\mathrm{GmbH}$ ) were obtained from a local pharmacy. For i.v. injection, cimetidine solution was diluted 1:1 with physiological saline solution $(0.9 \%, w / v)$ and injected at a volume of $6 \mu \mathrm{L}$ per g body weight. Sulpiride solution was diluted 1:8 with physiological saline solution and injected at a volume of $4 \mu \mathrm{L}$ per $\mathrm{g}$ body weight.

\section{Radiotracer Synthesis}

$\left[{ }^{11} \mathrm{C}\right]$ Metoclopramide was synthesized as previously described (17). For i.v. injection into mice, $\left[{ }^{11} \mathrm{C}\right]$ metoclopramide was formulated in physiological saline solution. For experiments in which a pharmacological dose of unlabeled metoclopramide was co-injected with $\left[{ }^{11} \mathrm{C}\right]$ metoclopramide, undiluted metoclopramide solution (Paspertin $囚$ ) was directly added to the formulated radiotracer solution.

\section{Animals}

Female wild-type C57BL/6 mice were obtained from Charles River Laboratories (Sulzfeld, Germany), male and female FVB wild-type mice were obtained from Envigo (Venray, The Netherlands), and male and female Slc22a1/2 $2^{(-/)}$mice (in an FVB genetic background) were obtained from the central animal facility at the University Hospital Münster (Münster, Germany). At the time of experiment, wild-type animals (C57BL/6 and FVB) were 6-12 weeks old and weighed $20.5 \pm 2.9 \mathrm{~g}$ and $S l c 22 a 1 / 2^{(-/)}$mice were 21 weeks old and weighed $28.4 \pm 2.6 \mathrm{~g}$. In total, 70 mice were used in the experiments. All animals were housed in type III IVC cages under controlled environmental conditions $(21.8 \pm$ $1.0^{\circ} \mathrm{C}, 40 \%$ to $70 \%$ humidity, 12-h light/dark cycle) with free access to standard laboratory rodent diet (LASQCidiet ${ }^{\mathrm{TM}}$, 
LASvendi, Soest, Germany) and water. An acclimatization period of at least 1 week was allowed before the animals were used in the experiments. The study was approved by the national authorities (Amt der Niederösterreichischen Landesregierung, approval numbers: LF1-TVG-48/0432019 and LF1-TVG-62/003-2020) and study procedures were in accordance with the European Communities Council Directive of September 22, 2010 (2010/63/EU). The animal experimental data reported in this study are in compliance with the ARRIVE (Animal Research: Reporting in Vivo Experiments) guidelines.

\section{Experimental Design}

Table I summarizes the different groups of animals examined in this study. Five groups of female C57BL/6 wild-type mice underwent 90-min PET scans after i.v. administration of a microdose $(<1 \mu \mathrm{g})$ of $\left[{ }^{11} \mathrm{C}\right]$ metoclopramide. Two of these groups received a co-injection with pharmacological doses of unlabeled metoclopramide ( 5 and $10 \mathrm{mg} / \mathrm{kg}$ respectively). The doses of coinjected unlabeled metoclopramide were selected based on previous work by Caillé et al. (17). Two further groups received an i.v. pretreatment with either cimetidine $(150 \mathrm{mg} / \mathrm{kg})$ or sulpiride (25 mg/kg) at $5 \mathrm{~min}$ before the start of the PET scan. The doses of cimetidine and sulpiride were selected based on previous work by Jensen et al. and Takano et al. (31, 32). Four additional groups of female C57BL/6 mice were used to assess radiolabeled metabolites at 15 min after i.v. injection of $\left[{ }^{11} \mathrm{C}\right]$ metoclopramide without and with co-administration of either unlabeled metoclopramide $(5 \mathrm{mg} / \mathrm{kg})$, cimetidine (150 mg/kg), or sulpiride (25 mg/kg). Two groups of male and female FVB wild-type $(n=4 / 4)$ and Slc22a1/2 $2^{(-)}$mice $(n=3 /$ 3) underwent 15-min PET scans after i.v. administration of $\left[{ }^{11} \mathrm{C}\right]$ metoclopramide followed by blood sampling and organ collection to assess radiolabeled metabolites of $\left[{ }^{11} \mathrm{C}\right]$ metoclopramide.

\section{Metabolism}

Different animal groups (Table I) were i.v. injected under isoflurane/air anesthesia with $\left[{ }^{11} \mathrm{C}\right]$ metoclopramide $(28 \pm$ $12 \mathrm{MBq}$, corresponding to $0.4 \pm 0.4 \mu \mathrm{g}$ of unlabeled metoclopramide). At $15 \mathrm{~min}$ after radiotracer injection, blood was collected from the retro-bulbar plexus and animals were killed by cervical dislocation while under deep anesthesia. Blood was centrifuged to obtain plasma, the liver and the kidneys were removed and urine was collected. Proteins were precipitated by the addition of acetonitrile $(1 \mu \mathrm{L} / \mu \mathrm{L}$ plasma; $1000 \mu \mathrm{L}$ for the liver, $200 \mu \mathrm{L}$ for the kidneys and $0.5 \mu \mathrm{L} / \mu \mathrm{L}$ urine). All solutions were vortexed and centrifuged. Each supernatant (plasma, liver, kidneys and urine, $5 \mu \mathrm{L}$ each) and diluted $\left[{ }^{11} \mathrm{C}\right]$ metoclopramide solution as a reference were spotted on thin-layer chromatography (TLC) plates (silica gel 60F
$254 \mathrm{~nm}, 10 \times 20 \mathrm{~cm}$; Merck, Darmstadt, Germany) and the plates were developed in ethyl acetate/ethanol/ammonium hydroxide $(25 \%, w / v)(80 / 20 / 5, v / v / v)$. Detection was performed by placing the TLC plates on multisensitive phosphor screens (PerkinElmer Life Sciences, Waltham, MA). The screens were scanned at 300 dpi resolution using a PerkinElmer Cyclone ${ }^{\circledR}$ Plus Phosphor Imager (PerkinElmer Life Sciences). The retardation factor $\left(\mathbf{R}_{\mathrm{f}}\right)$ for $\left[{ }^{1} \mathrm{C}\right]$ metoclopramide was 0.6 , while the radiolabeled metabolites remained on the start $\left(\mathrm{R}_{\mathrm{f}}=0\right)$.

\section{PET Imaging}

PET imaging was performed under isoflurane/air anesthesia and animals were warmed throughout the experiment while constantly monitoring body temperature and respiratory rate. A microPET Focus220 scanner (Siemens Medical Solutions, Knoxville, TN, USA) was used for PET imaging. $\left[{ }^{11} \mathrm{C}\right]$ Metoclopramide was administered in a volume of $100 \mu \mathrm{L}$ as an i.v. bolus $(34 \pm 8 \mathrm{MBq}$, corresponding to $0.2 \pm 0.1 \mu \mathrm{g}$ of unlabeled metoclopramide). A 90-min or 15-min dynamic PET scan was initiated at the start of radiotracer injection for the C57BL/6 mouse groups and for the FVB mouse groups, respectively. List mode data were acquired with a timing window of $6 \mathrm{~ns}$ and an energy window of 250-750 keV. At the end of the PET scans, blood was collected from the retro-bulbar plexus and animals were killed by cervical dislocation. Blood was centrifuged to obtain plasma and aliquots of blood and plasma were counted for radioactivity in a gamma counter. In the FVB mouse groups, organs and fluids were collected at the end of the 15-min PET scan and analyzed for radiolabeled metabolites of $\left[{ }^{11} \mathrm{C}\right]$ metoclopramide as described above.

\section{PET Data Analysis}

The PET data from the C57BL/6 mice were sorted into 25 time frames, the duration of which increased from $5 \mathrm{~s}$ to $20 \mathrm{~min}$, and the PET data from the FVB mice were sorted into 18 time frames with a duration increasing from $5 \mathrm{~s}$ to 5 min. PET images were reconstructed using Fourier rebinning of the 3-dimensional sinograms followed by a 2dimensional filtered back-projection with a ramp filter giving a voxel size of $0.4 \times 0.4 \times 0.796 \mathrm{~mm}^{3}$. Using the medical image data examiner software AMIDE (33), the left ventricle of the heart (image-derived arterial blood curve), brain, liver, left kidney and urinary bladder were manually outlined as regions of interest on the PET images, guided by representative magnetic resonance images obtained for a few animals on a 1-T benchtop MR scanner (ICON; Bruker BioSpin GmbH), to derive concentration-time curves expressed in units of percent injected dose per $\mathrm{mL}(\% \mathrm{ID} / \mathrm{mL})$. 
Table I Overview of Animal Groups Examined in the Study

\begin{tabular}{|c|c|c|c|}
\hline Study type & Genetic background; sex & Group & $n$ \\
\hline \multirow[t]{5}{*}{$\mathrm{PET}^{\mathrm{a}}$} & \multirow[t]{5}{*}{ C57BL/6; female } & Baseline & 5 \\
\hline & & $\begin{array}{l}\text { Metoclopramide } \\
(5 \mathrm{mg} / \mathrm{kg})\end{array}$ & 6 \\
\hline & & $\begin{array}{l}\text { Metoclopramide } \\
\quad(10 \mathrm{mg} / \mathrm{kg})\end{array}$ & 4 \\
\hline & & $\begin{array}{l}\text { Cimetidine } \\
\quad(150 \mathrm{mg} / \mathrm{kg})\end{array}$ & 4 \\
\hline & & Sulpiride (25 mg/kg) & 6 \\
\hline \multirow[t]{4}{*}{ Metabolism ${ }^{\text {b }}$} & \multirow[t]{4}{*}{ C57BL/6; female } & Control & 4 \\
\hline & & $\begin{array}{l}\text { Metoclopramide } \\
(5 \mathrm{mg} / \mathrm{kg})\end{array}$ & 6 \\
\hline & & $\begin{array}{l}\text { Cimetidine } \\
\qquad(150 \mathrm{mg} / \mathrm{kg})\end{array}$ & 4 \\
\hline & & Sulpiride (25 mg/kg) & 4 \\
\hline \multirow[t]{2}{*}{ PET + metabolism ${ }^{c}$} & \multirow[t]{2}{*}{ FVB; male/female } & Wild-type & $4 / 4$ \\
\hline & & $S / c 22 a l / 2^{(-1-)}$ & $3 / 3$ \\
\hline
\end{tabular}

a PET scan lasted $90 \mathrm{~min}$

${ }^{b}$ Metabolites in the organs and fluids were measured at 15 min after radiotracer injection. Animals did not undergo a PET scan

' PET scan lasted I 5 min, then organs and fluids from all scanned animals were collected and metabolites were measured

\section{Kinetic Analysis}

The area under the concentration-time curves (AUC, \% \% / $\mathrm{mL} \times \mathrm{min}$ ) was calculated for each region of interest using Prism 8 Software (GraphPad, La Jolla, CA, USA). The kidney and liver uptake rate constants $\left(k_{\text {uptake,kidney }}\right.$ and $k_{\text {uptake,liver, }}$ respectively - $\mathrm{mL} / \mathrm{min} / \mathrm{mL}$ tissue) of radioactivity were estimated from 0.4 to 4 min after $\left[{ }^{11} \mathrm{C}\right.$ ] metoclopramide injection by integration plot analysis (34):

$\frac{\mathrm{X}_{\mathrm{t}, \text { tissue }}}{\mathrm{C}_{\mathrm{t}, \text { blood }}}=k_{\text {uptake,tissue }} \mathrm{x} \frac{\mathrm{AUC}_{0-\mathrm{t}, \text { blood }}}{\mathrm{C}_{\mathrm{t}, \text { blood }}}+\mathrm{V}_{\mathrm{E} \text {,tissue }}$ where $\mathrm{X}_{\mathrm{t}, \text { tissue }}$ is the amount of radioactivity per $\mathrm{mL}$ tissue in the kidney or liver at time $\mathrm{t}, \mathrm{C}_{\mathrm{t} \text {,blood }}$ is the radioactivity concentration in the blood (image-derived curve from the region of interest placed in the left ventricle of the heart) at time $t$, and $\mathrm{AUC}_{0 \text {-t,blood }}$ is the area under the concentration-time curve of the left ventricle of the heart from time 0 to time $t$. $V_{E}$ corresponds to the $y$-intercept of the integration plot. $k_{\text {uptake,tissue }}$ is obtained by performing linear regression analysis of a plot of $\mathrm{X}_{\mathrm{t} \text {,tissue }} / \mathrm{C}_{\mathrm{t}, \text { blood }}$ versus $\mathrm{AUC}_{0 \text {-t,blood }} / \mathrm{C}_{\mathrm{t} \text {,blood }}$ and calculating the slope of the regression line. The intrinsic urinary excretion clearance of total radioactivity $\left(\mathrm{CL}_{\text {int,urine }}, \mathrm{mL} / \mathrm{min}\right)$ was calculated for the animals which underwent 90-min PET scans from 30 to 70 min after radiotracer injection using integration plot analysis (34) as follows:

$\mathrm{X}_{\mathrm{t}, \text { urine }}=\mathrm{CL}_{\text {int,urine }} \mathrm{x} \mathrm{AUC}_{0-\mathrm{t}, \text { kidney }}+\mathrm{V}_{\mathrm{E}}$

where $\mathrm{X}_{\mathrm{t} \text {,urine }}$ is the total amount of radioactivity excreted in urine at time $\mathrm{t}$, and $\mathrm{AUC}_{0 \text {-t,kidney }}$ is the area under the concentration-time curve of the kidney from time 0 to time t. $\mathrm{V}_{\mathrm{E}}$ is the y-intercept of the integration plot. $\mathrm{CL}_{\text {int,urine }}$ was obtained by performing linear regression analysis of a plot of $\mathrm{X}_{\text {int,urine }}$ versus $\mathrm{AUC}_{0 \text {-t,kidney }}$ and calculating the slope of the regression line.

The total radioactivity concentration ratios (kidney/plasma, liver/plasma and urine/kidney) were calculated using the following equation:

Concentration ratio $=\frac{\text { Concentration }_{\text {total PET, tissue }}}{\text { Concentration }_{\text {total PET, tissue } 2}}$

where Concentration total PET,tissuel and Concentration $_{\text {total }}$ PET,tissue 2 are the $\% \mathrm{DD} / \mathrm{mL}$ values of total radioactivity obtained at 15 min after radiotracer injection from the PET images. The plasma concentration was obtained by multiplying the concentration in the left ventricle of the heart by the plasma/blood radioactivity ratio, determined from the blood sample collected at the end of the PET scan.
Table II Percentage of Unchanged $\left[{ }^{\prime \prime} \mathrm{C}\right]$ Metoclopramide in Different Organs or Fluids Determined with Radio-TLC Analysis at I 5 Min After Radiotracer Injection

\begin{tabular}{|c|c|c|c|c|c|c|}
\hline \multirow{2}{*}{$\begin{array}{l}\text { Group } \\
\text { Genetic back-ground; sex }\end{array}$} & & \multirow[t]{2}{*}{$n$} & \multicolumn{4}{|l|}{ Organ } \\
\hline & & & Plasma & Kidney & Urine & Liver \\
\hline \multirow[t]{5}{*}{ C57BL/6; female } & Baseline & 4 & $18 \pm 2$ & $64 \pm 6$ & $29 \pm 4$ & $57 \pm 4$ \\
\hline & Metoclopramide (5 mg/kg) & 6 & $37 \pm 4$ & $74 \pm 4$ & $43 \pm 7$ & $76 \pm 4$ \\
\hline & Cimetidine & 4 & $89 \pm 2 * * * *$ & $96 \pm 2 * * *$ & $87 \pm 4$ *** & $96 \pm 2$ ***** \\
\hline & $\begin{array}{l}\text { (150 mg/kg) } \\
\text { Sulpiride }\end{array}$ & 4 & $37 \pm 11$ & $75 \pm 5$ & $36 \pm 5$ & $76 \pm 7$ \\
\hline & $(25$ mg/kg) & & & & & \\
\hline FVB; male/female & $\begin{array}{l}\text { Wild-type } \\
69 \pm 6\end{array}$ & 4/ & 4 & $23 \pm 7$ & $70 \pm 20$ & $64 \pm 22$ \\
\hline SIc22al/2(-1-) & $3 / 3$ & 25 & \pm 6 & $72 \pm 8$ & $48 \pm 10$ & $74 \pm 9$ \\
\hline
\end{tabular}

Percentage of unchanged radiotracer is given as mean $\pm \mathrm{SD}$. *** $p<0.0$ I, **** $p<0.00$ I, Kruskal-Wallis followed by a Dunn's multiple comparison test against a reference group (baseline) 
Fig. I Serial PET images of a representative C57BL/6 wild-type mouse without (baseline) and with pretreatment with cimetidine ( $150 \mathrm{mg} / \mathrm{kg}$ ) at $5 \mathrm{~min}$ before injection of [ ' C]metoclopramide. Two different coronal views are shown in order to visualize all the excretory organs. Radioactivity concentration is expressed as percent of the injected dose per $\mathrm{mL}(\% \mathrm{ID} / \mathrm{mL})$. Anatomical structures are labeled with white arrows (K: kidney; L: liver; UB: urinary bladder).

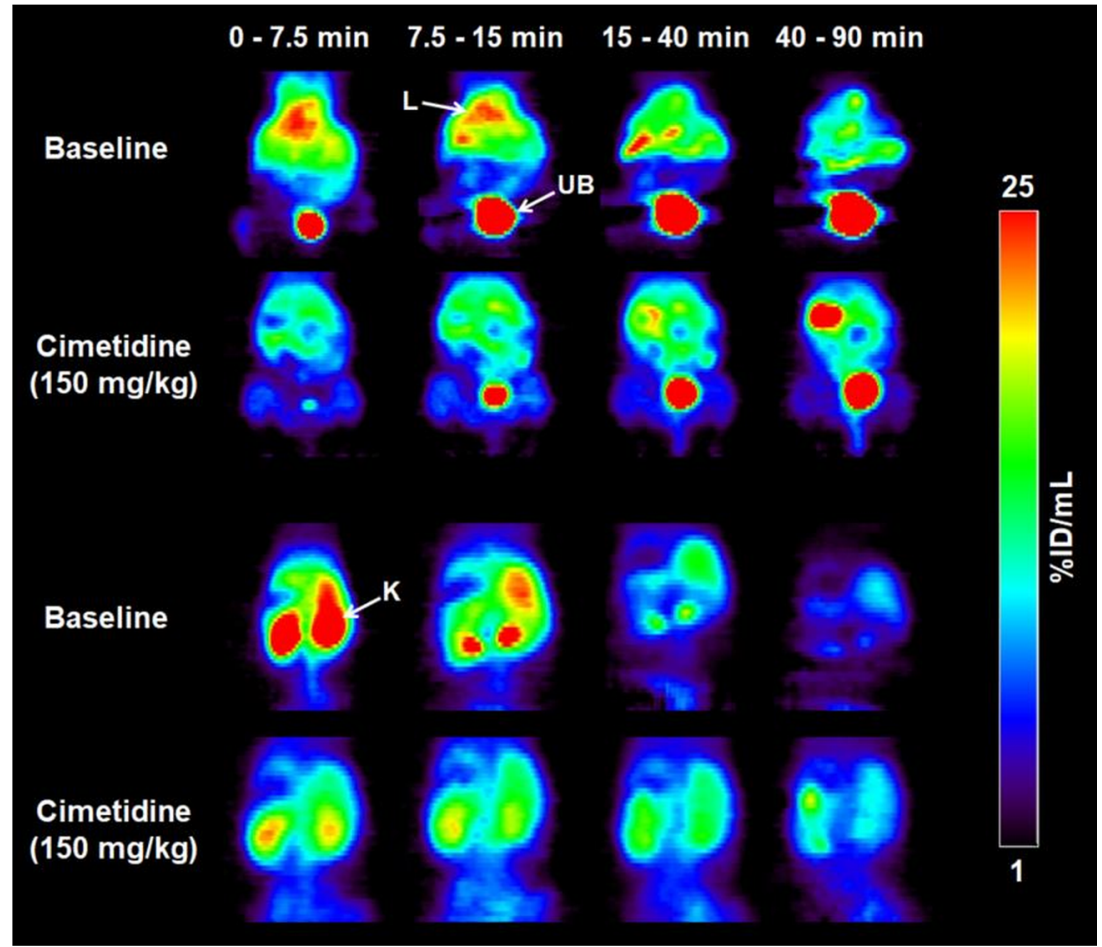

Since $\left[{ }^{11} \mathrm{C}\right]$ metoclopramide is highly metabolized in mice, total radioactivity was corrected for radiolabeled metabolites in order to calculate the concentration ratios of unchanged $\left[{ }^{1} \mathrm{C}\right]$ metoclopramide. The correction for metabolites of the total radioactivity concentration in each organ was performed using the following equation:

Concentration $_{\text {metabolite }- \text { corrected }}=$ Concentration $_{\text {total PET }} \times \mathrm{P}_{\text {unchanged }} / 100$

Fig. 2 Mean time-radioactivity curves $(\% \mathrm{ID} / \mathrm{mL}$ or $\% \mathrm{ID} \pm \mathrm{SD})$ in the blood (image-derived blood curve from the left ventricle of the heart), left kidney, liver and urinary bladder of wild-type C57BL/6 mice for the baseline group, and groups treated with $5 \mathrm{mg} / \mathrm{kg}$ or $10 \mathrm{mg} / \mathrm{kg}$ metoclopramide, 150 mg/kg cimetidine or $25 \mathrm{mg} / \mathrm{kg}$ sulpiride.
Blood

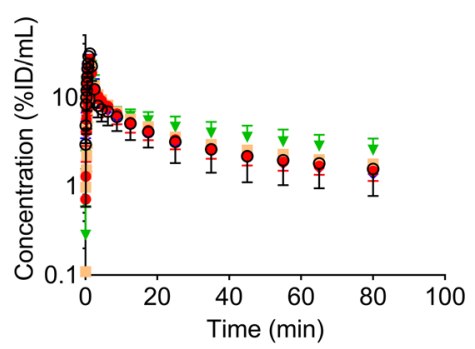

Liver

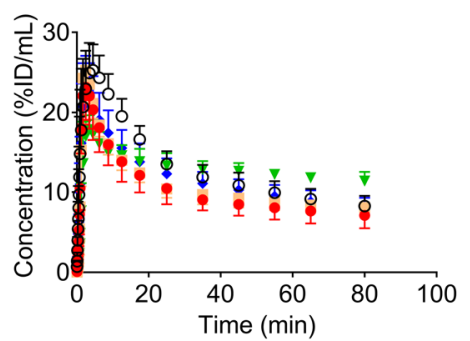

where Concentration total $_{\text {PET }}$ is the $\% \mathrm{ID} / \mathrm{mL}$ value of total radioactivity obtained at $15 \mathrm{~min}$ after radiotracer injection from the PET images and $\mathrm{P}_{\text {unchanged }}$ is the average percentage of unchanged $\left[{ }^{11} \mathrm{C}\right]$ metoclopramide in each sampled organ or fluid (Table II). No metabolite data at $15 \mathrm{~min}$ after radiotracer injection were available for the PET scanned animals with C57BL/6 genetic background, since the PET scan lasted 90 min; thus, $\mathrm{P}_{\text {unchanged }}$ was used from the separate cohort of $\mathrm{C} 57 \mathrm{BL} / 6$

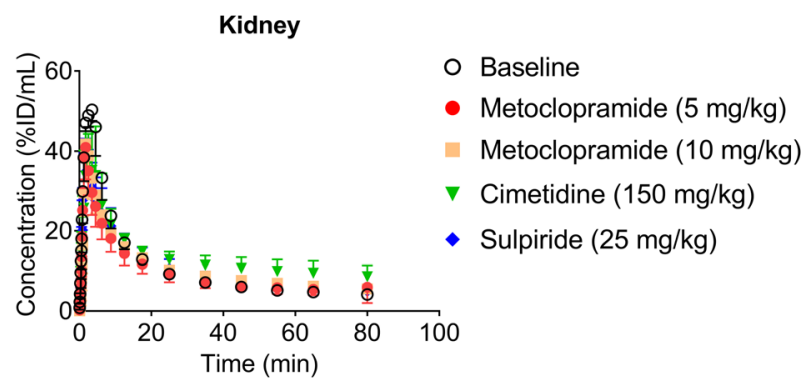

Urinary bladder

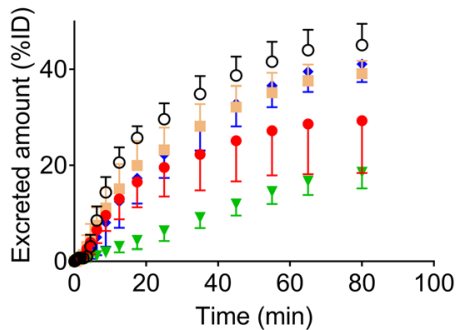


animals which did not undergo a PET scan (Table I). For the PET scanned animals with FVB genetic background, $\mathrm{P}_{\text {unchanged }}$ was measured at the end of the 15-min PET scans for all animals.

\section{Statistical Analysis}

Statistical analysis was done using Prism 8 software. Differences between two groups were analyzed by a Mann-Whitney test, and differences between multiple groups were analyzed by Kruskal-Wallis tests followed by a Dunn's multiple comparison test against the baseline group. The level of statistical significance was set to $p \leq 0.05$.

\section{RESULTS}

In this study we used PET to study the influence of cation transporters on the renal and hepatobiliary disposition of $\left[{ }^{11} \mathrm{C}\right]$ metoclopramide. First, the dose dependency of $\left[{ }^{11} \mathrm{C}\right]$ metoclopramide disposition and the effect of prototypical cation transporter inhibitors (cimetidine and sulpiride) were investigated. We further assessed metabolism of $\left[{ }^{11} \mathrm{C}\right]$ metoclopramide by analyzing extracts from different organs and fluids collected at 15 min after $\left[{ }^{11} \mathrm{C}\right]$ metoclopramide injection, either in separate groups of mice or in the same animals that underwent PET imaging (see Table I) with radio-TLC. These experiments revealed that $\left[{ }^{11} \mathrm{C}\right]$ metoclopramide was metabolized to a significant extent at 15 min after i.v. administration (Table II). Cimetidine significantly increased the percentage of unchanged $\left[{ }^{11} \mathrm{C}\right]$ metoclopramide in all analyzed organs and fluids, while unlabeled metoclopramide and sulpiride also showed a trend towards increasing the percentage of unchanged $\left[{ }^{11} \mathrm{C}\right]$ metoclopramide, but without reaching statistical significance (Table II). Serial PET images of a representative C57BL/6 wild-type mouse (Fig. 1) showed that after i.v. injection of $\left[{ }^{11} \mathrm{C}\right]$ metoclopramide, radioactivity was rapidly taken up by the kidneys and the liver. After some time, radioactivity was excreted into the urinary bladder, while the intestine was hardly identifiable on the PET images. Timeradioactivity curves for the selected organs are shown in Fig. 2. Maximum concentration of radioactivity in the kidneys and liver was reached within 5 min after $\left[{ }^{11} \mathrm{C}\right]$ metoclopramide injection and corresponded to amounts of approximately $17 \%$ and $36 \%$ of the injected dose, respectively, assuming average mouse organ volumes published in the literature (35). The amount of radioactivity excreted into the urinary bladder at the end of the 90-min PET scan corresponded to approximately $45 \%$ of the injected dose. As compared to the other studied organs, differences in the PETderived urinary bladder kinetics between groups appeared to
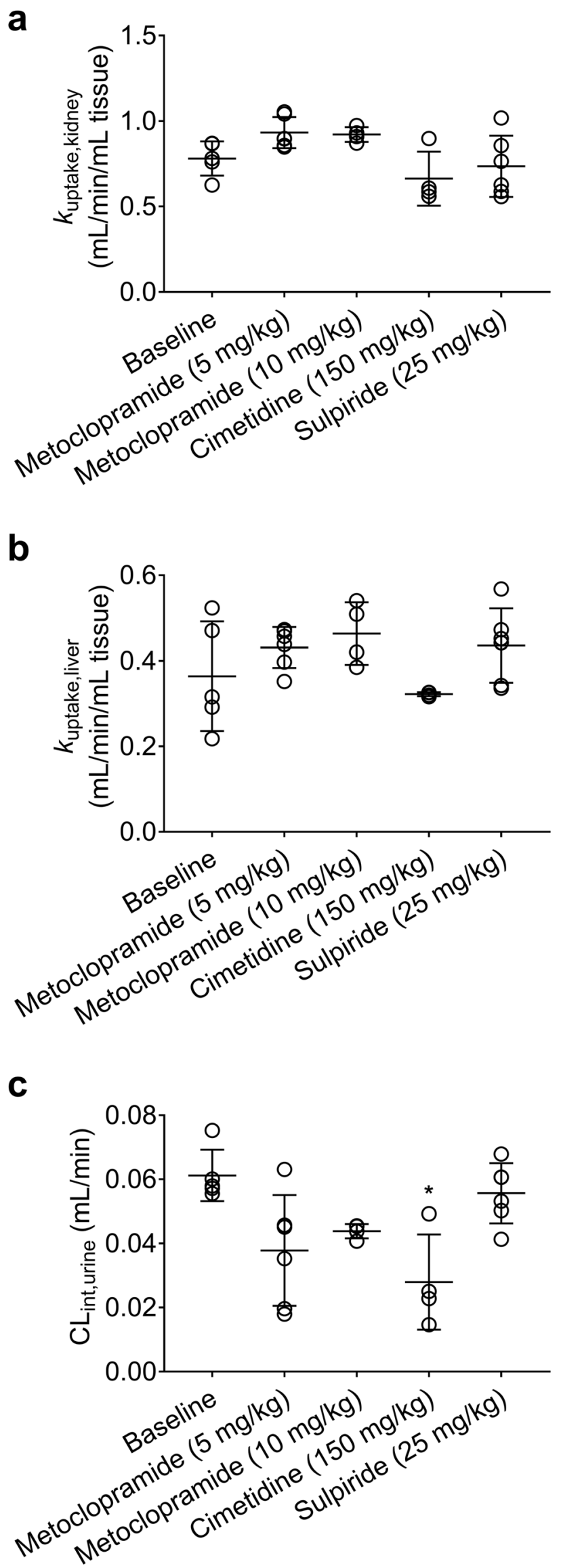
4 Fig. 3 Kidney (a) and liver (b) uptake rate constants and intrinsic urinary excretion clearance (c) of total radioactivity in C57BL/6 wild-type mice (baseline), wild-type mice co-injected with unlabeled metoclopramide (5 and $10 \mathrm{mg} / \mathrm{kg}$ ) and wild-type mice pretreated with cimetidine (I50 mg/kg) or sulpiride $(25 \mathrm{mg} / \mathrm{kg})$. * $p<0.05$, Kruskal-Wallis followed by Dunn's multiple comparison test against the reference (baseline) group.

be more pronounced, especially after pretreatment with cimetidine as compared to the baseline group (Figs. 1 and 2).

Integration plot analysis was used to estimate the rate constants for uptake of total radioactivity from blood into the kidneys $\left(k_{\text {uptake,kidney }}\right)$ or into the liver $\left(k_{\text {uptake,liver }}\right) \cdot k_{\text {uptake,kidney }}$ values were in the range of $0.5-1 \mathrm{~mL} / \mathrm{min} / \mathrm{mL}$ kidney (Fig. 3a), which was below the kidney blood flow rate in mice (3.8 $\mathrm{mL} / \mathrm{min} / \mathrm{mL}$ kidney) (35). $k_{\text {uptake,liver values ranged from }}$ $0.2-0.6 \mathrm{~mL} / \mathrm{min} / \mathrm{mL}$ liver (Fig. $3 \mathrm{~b}$ ), which was lower than the liver blood flow rate in mice $(1.4 \mathrm{~mL} / \mathrm{min} / \mathrm{mL}$ liver $)(35)$. No significant differences in $k_{\text {uptake,kidney }}(p=0.3873$ and 0.2554 for 5 and $10 \mathrm{mg} / \mathrm{kg}$ metoclopramide co-administration, respectively and $p>0.9999$ for cimetidine and sulpiride pretreatment) and $k_{\text {uptake,liver }}(p=0.7931,0.4383$ and 0.7422 for 5 and $10 \mathrm{mg} / \mathrm{kg}$ metoclopramide and sulpiride co-administration, respectively, and $p>0.9999$ for cimetidine pretreatment) were observed between the different treatment groups and the baseline group (Fig. $3 \mathrm{a}$ and $\mathrm{b}$ ).

Due to the differences in $\left[{ }^{11} \mathrm{C}\right]$ metoclopramide metabolism between groups, it was not straightforward to distinguish transporter effects from metabolism effects from the PET data alone. Therefore, PET-derived total radioactivity concentrations in different organs and fluids at the time point of $15 \mathrm{~min}$ after radiotracer injection were corrected for radiolabeled metabolites of $\left[{ }^{11} \mathrm{C}\right]$ metoclopramide determined with radioTLC analysis (Table II). This correction revealed up to 3-fold increases in the concentration of unchanged $\left[{ }^{11} \mathrm{C}\right]$ metoclopramide in plasma for all investigated treatments as compared with the baseline group, which was statistically significant in the case of cimetidine $(p=0.0007)$ (Fig. 4a). We next determined concentration ratios of unchanged $\left[{ }^{11} \mathrm{C}\right]$ metoclopramide (kidney/plasma, liver/plasma, and urine/kidney) for the $15 \mathrm{~min}$ time point (Fig. 5). Coadministration with $5 \mathrm{mg} / \mathrm{kg}$ metoclopramide and with cimetidine caused a significant decrease in the uptake of unchanged $\left[{ }^{1} \mathrm{C}\right]$ metoclopramide from plasma into both kidney (Fig. 5a) ( $p=0.0165$ and 0.0132, respectively) and liver (Fig. 5b) $(p=$ 0.0091 and 0.0003 , respectively).

Cimetidine pretreatment caused a significant reduction $(p=0.0207)$ in the intrinsic urinary excretion clearance of total radioactivity $\left(\mathrm{CL}_{\text {int,urine }}\right.$ (Fig. $\left.3 \mathrm{c}\right)$. There was also a trend towards a decrease in $\mathrm{CL}_{\text {int,urine }}$ after co-administration of $5 \mathrm{mg} / \mathrm{kg}$ and $10 \mathrm{mg} / \mathrm{kg}$ of metoclopramide, but statistical significance was not reached. In addition, after pretreatment with cimetidine there was a reduction in the urine/kidney concentration ratio at $15 \mathrm{~min}$ after radiotracer injection, which was more pronounced for total $(p=0.0009)$ than for metabolite-corrected radioactivity concentrations $(p=$ 0.0031) (Fig. 5c).

\section{a}

Plasma

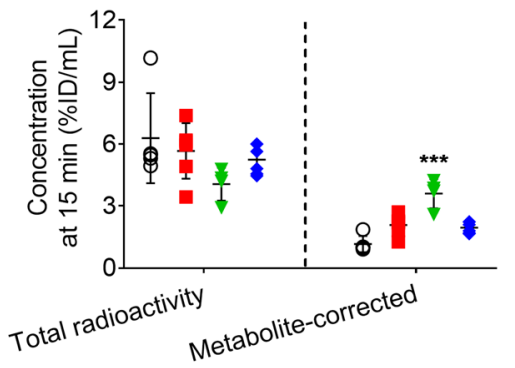

- Baseline

- Metoclopramide $(5 \mathrm{mg} / \mathrm{kg})$

$\checkmark$ Cimetidine $(150 \mathrm{mg} / \mathrm{kg})$

- Sulpiride $(25 \mathrm{mg} / \mathrm{kg})$

b

Plasma

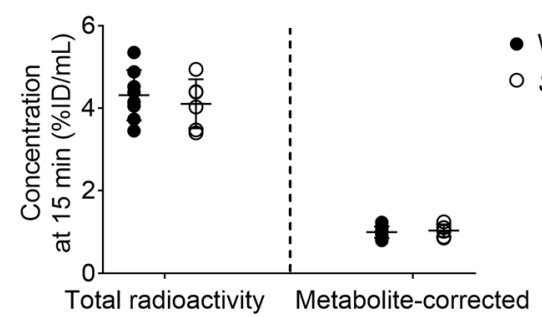

Fig. 4 Total (left side of each panel) and metabolite-corrected radioactivity concentrations (right side of each panel, corresponding to unchanged $\left[{ }^{\prime \prime} \mathrm{C}\right]$ metoclopramide) in the plasma of C57BL/6 at $15 \mathrm{~min}$ after [ [ ' C]metoclopramide injection in wild-type mice without and with co-administration of metoclopramide (5 or $10 \mathrm{mg} / \mathrm{kg}$ ) or pretreatment with cimetidine $(150 \mathrm{mg} / \mathrm{kg})$ or sulpiride $(25 \mathrm{mg} / \mathrm{kg})(\mathbf{a})$ and in wild-type and S/c22al/2(-/-) $\mathrm{FVB}$ mice (b). **** $p<0.00$ I, Kruskal-Wallis followed by a Dunn's multiple comparison test against the reference (baseline) group. 
a

Kidney/plasma
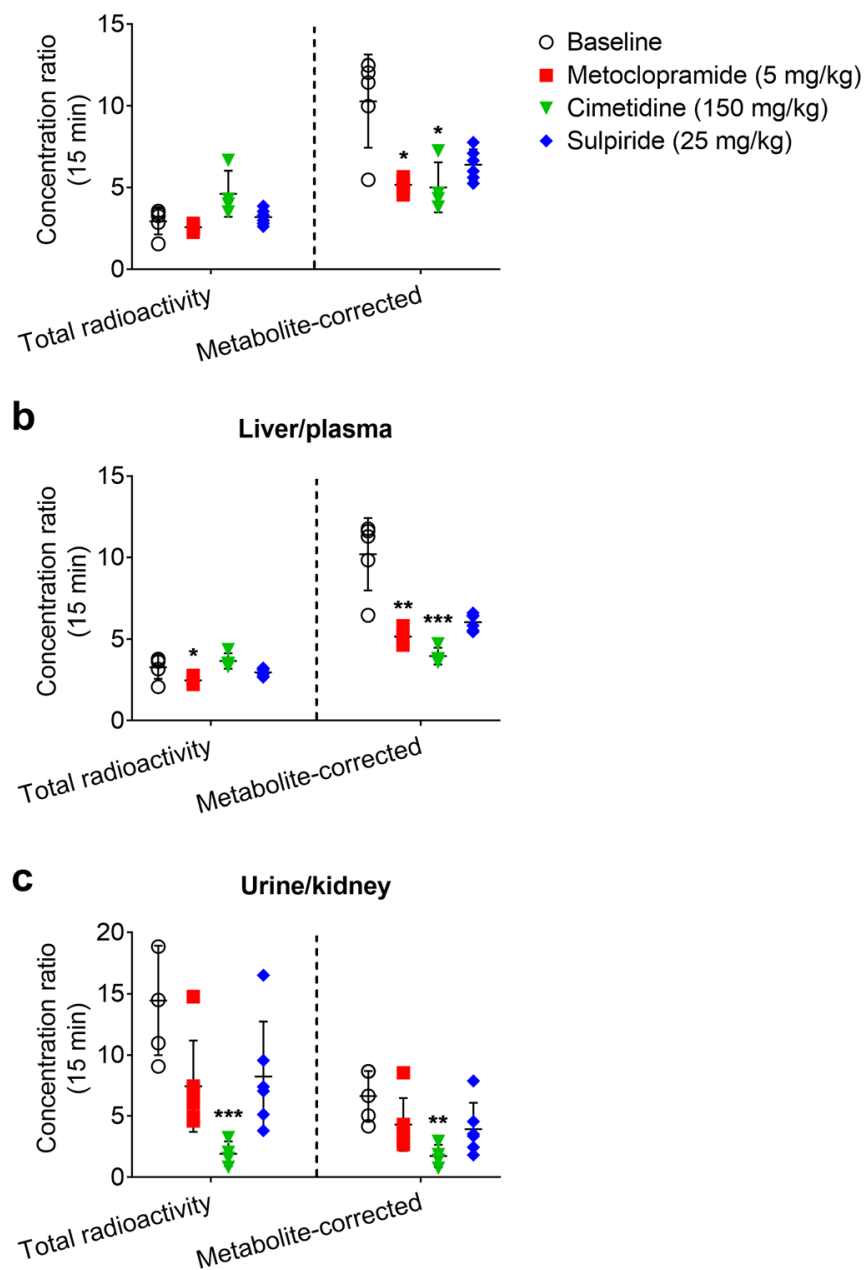

Fig. 5 Kidney/plasma (a), liver/plasma $(\mathbf{b})$ and urine/kidney $(\mathbf{c})$ concentration ratios calculated at I 5 min after radiotracer injection. Differences between groups were assessed from total PET radioactivity (left side of each panel) or from PET radioactivity corrected for radiolabeled metabolites (right side of each panel, corresponding to unchanged [ ' C] metoclopramide). ${ }^{*} p<0.05$, ** $p<0.01$, **** $p<0.00$ I, Kruskal-Wallis followed by a Dunn's multiple comparison test against the reference (baseline) group.

The correction of the PET data at 15 min for radiolabeled metabolites revealed that all treatments decreased the uptake of unchanged $\left[{ }^{11} \mathrm{C}\right]$ metoclopramide from plasma into both kidney and liver (Fig. 5a and b), which suggested an involvement of mouse OCT1 and OCT2. Thus, in order to further investigate the role of these uptake transporters in the kidney and liver uptake of $\left[{ }^{11} \mathrm{C}\right]$ metoclopramide, we performed 15min PET scans with $\left[{ }^{11} \mathrm{C}\right]$ metoclopramide in FVB wild-type and Slc22a1/2 $2^{(-/-)}$mice. $\left[{ }^{11} \mathrm{C}\right]$ Metoclopramide was metabolized to a similar extent in both mouse strains (Table II). Concentration-time curves for the different organs of wildtype and Slc22a1/2 $2^{(-)}$mice are shown in Fig. 6. The concentration of unchanged $\left[{ }^{11} \mathrm{C}\right]$ metoclopramide in plasma at $15 \mathrm{~min}$ after injection was not significantly different between the two mouse genotypes (Fig. 4b) $(p=0.5941$ and 0.6417 for total radioactivity and metabolite-corrected data, respectively). $k_{\text {uptake,kidney }}$ and $k_{\text {uptake, liver }}$ of total radioactivity were significantly lower ( $p=0.0027$ and 0.0127 , respectively) in Slc22a1/2 $2^{(-)}$mice than in wild-type mice (Fig. 7). Both kidney/plasma and liver/plasma concentration ratios calculated at $15 \mathrm{~min}$ after radiotracer injection were significantly lower in the knockout animals (kidney/plasma: $p=0.0246$ and 0.0080 ; liver/plasma: $p=0.0127$ and 0.0080 for total radioactivity and metabolite-corrected data, respectively), independent of metabolite correction (Fig. 8).

We also determined $\mathrm{AUC}_{\mathrm{brain}}$ values in all examined groups as a measure of brain exposure to $\left[{ }^{11} \mathrm{C}\right]$ metoclopramide (Fig. 9). $\mathrm{AUC}_{\text {brain }}$ showed a trend towards an increase for the $5 \mathrm{mg} / \mathrm{kg}$ and $10 \mathrm{mg} / \mathrm{kg}$ metoclopramide and for the cimetidine pretreated groups as compared to baseline, but statistical significance was not reached ( $p=0.0802,0.0514$ and 0.0912 , respectively). This trend was not observed for the sulpiride pretreated group $(p>0.9999)$. $\mathrm{AUC}_{\mathrm{brain}}$ did not differ between Slc22a1/2 $2^{(-)}$and wild-type mice (Fig. 9b). 
Blood

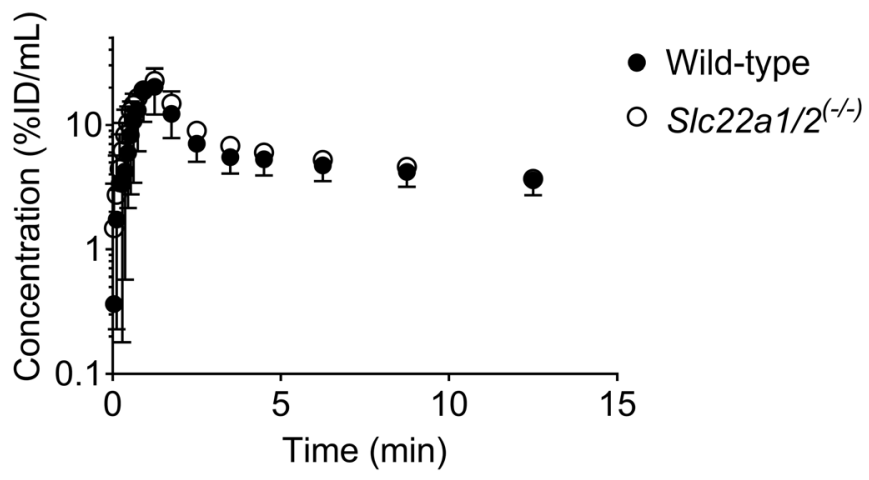

Kidney

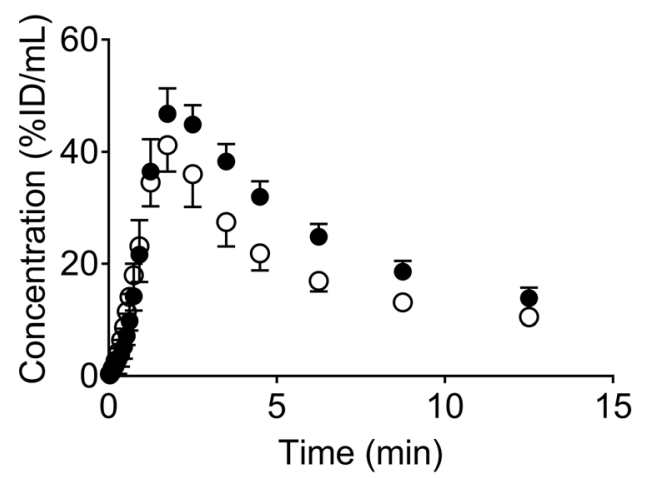

\section{Liver}

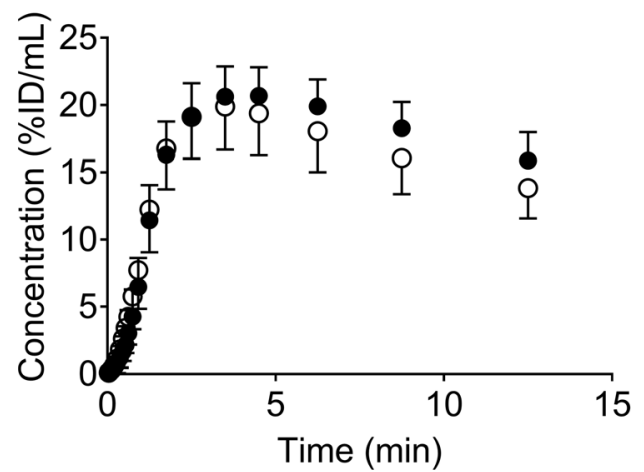

Fig. 6 Mean concentration-time curves $(\% \mathrm{ID} / \mathrm{mL} \pm \mathrm{SD})$ in the blood (image-derived blood curve), left kidney and liver of FVB wild-type and S/c22al/2(-/-) mice.

\section{DISCUSSION}

In the present study we used PET imaging in mice to assess the involvement of organic cation transporters (OCTs, MATEs) in the disposition of the radiolabeled antiemetic drug $\left[{ }^{1} \mathrm{C}\right]$ metoclopramide. This is of relevance as metoclopramide shows considerable inter-individual variability in its efficacy and side effects, and previous studies have provided evidence for non-linear, dose-dependent pharmacokinetics of metoclopramide in rats and humans $(9,14-16)$. Non-linear pharmacokinetics of metoclopramide were observed both after oral and i.v. administration, whereby effects appeared to be more pronounced after oral administration. Drug transporters are widely accepted determinants of drug disposition (25), and previous observations related to metoclopramide pharmacokinetics and pharmacodynamics may therefore be related to the effects of drug transporters.

Our data revealed that after i.v. injection into mice, $\left[{ }^{1} \mathrm{C}\right]$ metoclopramide undergoes metabolism in the liver to a significant extent followed by excretion of its radiolabeled metabolites into the urine, and that only a smaller portion of the drug is excreted in unchanged form into the urine. With a 
a

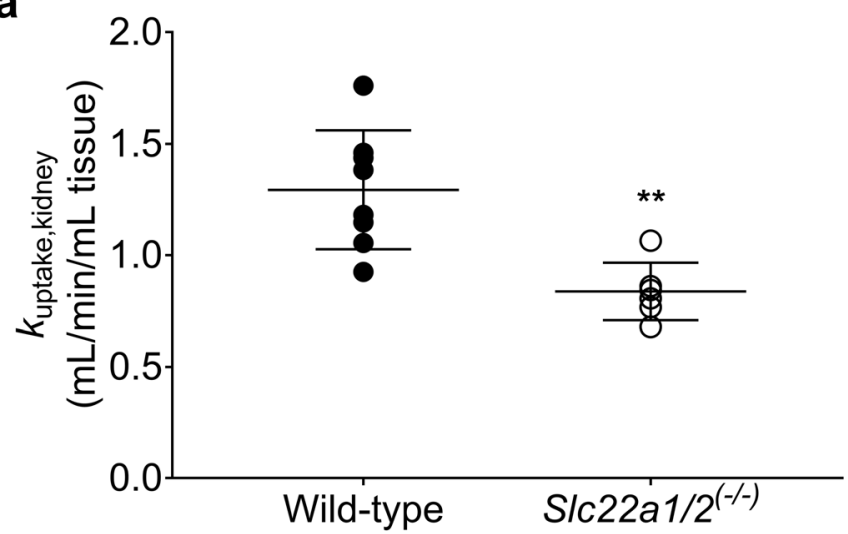

b

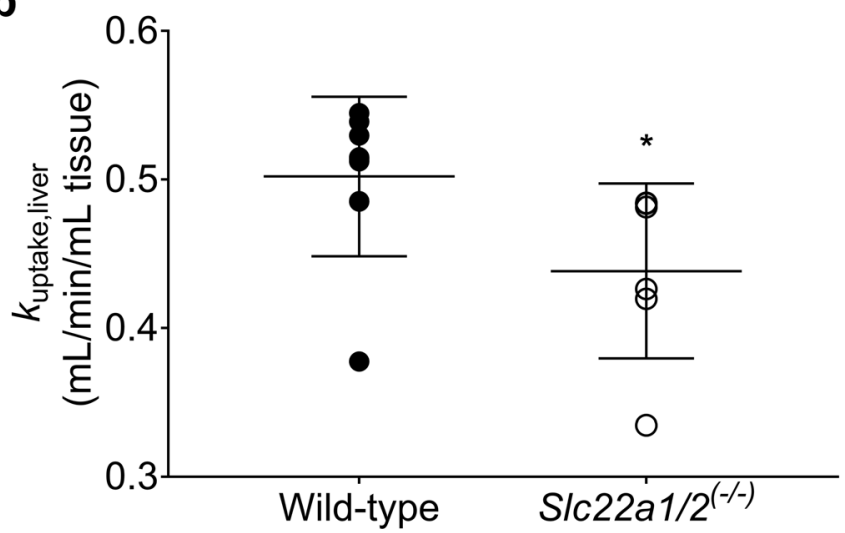

Fig. 7 Kidney $(\mathbf{a})$ and liver $(\mathbf{b})$ uptake rate constants of total radioactivity in FVB wild-type and SIc22a I/2 ${ }^{(-/)}$mice. * $p<0.05$, ** $p<0.0$ I, Mann-Whitney test.

predominant clearance by metabolism, $\left[{ }^{11} \mathrm{C}\right]$ metoclopramide differs from several previously investigated PET tracers for drug transporters, which were hardly metabolized and underwent mainly transporter-mediated excretion of the unchanged parent drug (30). As PET measures total radioactivity in tissue and cannot distinguish different chemical forms of radioactivity, the in vivo behavior of $\left[{ }^{11} \mathrm{C}\right]$ metoclopramide proved very challenging for PET analysis of its clearance pathways. We managed to overcome this limitation by combining the PET experiments with metabolism experiments, which allowed us to correct PET-derived tissue concentrations of total radioactivity at one selected time point of the experiments (i.e. at 15 min after radiotracer injection) for the contribution of radiolabeled metabolites. This approach enabled us to separate transporter effects from metabolism effects. Mice have a very small total blood volume (approximately $1.7 \mathrm{~mL}$ ), which makes it challenging to perform the repeated blood sampling needed for pharmacokinetic analysis. We therefore generated a PET image-derived blood curve from the left ventricle of the heart. PET-derived radioactivity concentrations in the left ventricle of the heart showed an excellent correlation with blood radioactivity concentrations measured in a gamma counter at the end of the PET scan $(r=0.9351, p<0.0001)$, which validated our approach to generating an image-derived blood curve in mice.
As a first step, we evaluated the dose dependency of $\left[{ }^{11} \mathrm{C}\right]$ metoclopramide pharmacokinetics by comparing $\left[{ }^{11} \mathrm{C}\right]$ metoclopramide disposition after administration of a microdose $(<1 \mu \mathrm{g})$ with the co-injection of two different pharmacological doses of unlabeled metoclopramide $(5$ and $10 \mathrm{mg} / \mathrm{kg}$ ). No dose dependency could be found for PETderived concentration-time curves of total radioactivity in blood and different tissues (Fig. 2). However, metabolite correction of the PET data at the time point of $15 \mathrm{~min}$ after radiotracer injection revealed that co-administration of a pharmacological dose of metoclopramide ( $5 \mathrm{mg} / \mathrm{kg}$ ) significantly decreased kidney/plasma and liver/plasma concentration ratios of unchanged $\left[{ }^{11} \mathrm{C}\right]$ metoclopramide (Fig. 5a,b). The decrease in the liver/plasma concentration ratio of unchanged $\left[{ }^{11} \mathrm{C}\right]$ metoclopramide was consistent with the previously reported decrease in the uptake rate constant of $\left[{ }^{1} \mathrm{C}\right]$ metoclopramide from plasma into the liver $\left(k_{\text {uptake,liver }}\right)$ in rats co-injected with $3 \mathrm{mg} / \mathrm{kg}$ of metoclopramide, determined using a metabolite-corrected, sampled arterial plasma input function (17). This supported the notion that pharmacological doses of metoclopramide lead to saturation of hepatic and renal uptake transporters.

We then aimed at identifying potential transporters involved in the tissue distribution and excretion of metoclopramide. Metoclopramide has been shown to be an in vitro 
a

Kidney/plasma

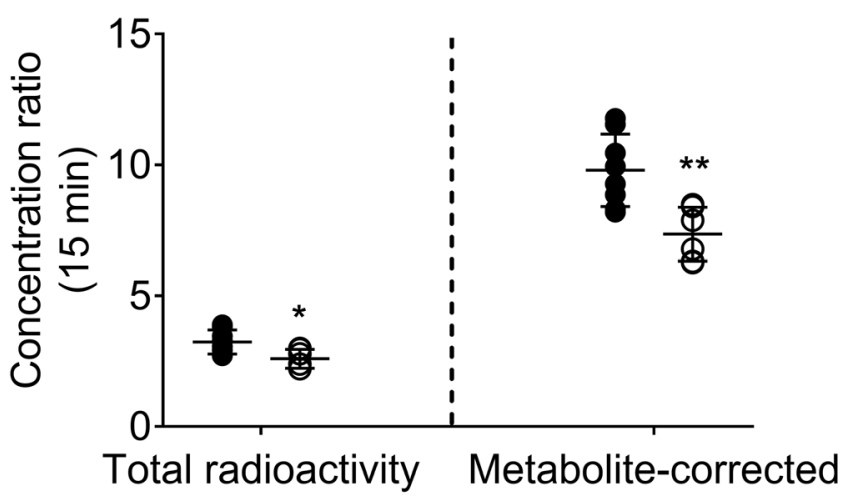

b Liver/plasma

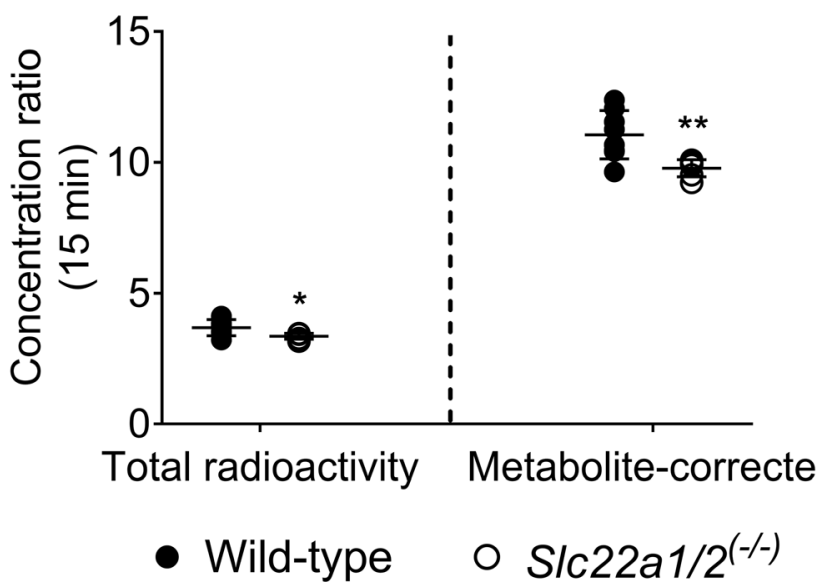

Fig. 8 Kidney/plasma (a) and liver/plasma (b) concentration ratios calculated at $15 \mathrm{~min}$ after radiotracer injection. Differences between groups were assessed from total PET radioactivity (left side of each panel) or from PET radioactivity corrected for radiolabeled metabolites (right side of each panel, corresponding to unchanged $\left[{ }^{\prime} \mathrm{C}\right]$ metoclopramide). $* p<0.05$, *** $p<$ 0.01, Mann-Whitney test.

substrate of human OCT1 and OCT2 (24). Therefore, the effect of two different prototypical cation transporter inhibitors on the disposition of $\left[{ }^{11} \mathrm{C}\right]$ metoclopramide was investigated. The first inhibitor was cimetidine, which was shown to be an inhibitor of mouse MATEs (inhibition constant $K_{\mathrm{i}}$ : $1-$ $4 \mu \mathrm{M})$ and mouse OCTs $\left(K_{\mathrm{i}}: 54-143 \mu \mathrm{M}\right)(36)$, and which has been successfully used at a dose of $150 \mathrm{mg} / \mathrm{kg}$ in a PET study in mice to reveal the contribution of mouse MATEs and OCTs to the liver and kidney disposition of the radiolabeled oral antidiabetic drug $\left[{ }^{11} \mathrm{C}\right]$ metformin (31). After pretreatment with cimetidine, we found a significant decrease in the kidney/plasma and liver/plasma ratios of unchanged $\left[{ }^{11} \mathrm{C}\right]$ metoclopramide at 15 min after injection and an approximately 3 -fold increase in the plasma concentration of $\left[{ }^{11} \mathrm{C}\right]$ metoclopramide, which supported an involvement of OGT1 and OCT2 in the kidney and liver uptake of a

AUC $_{\text {brain }}$

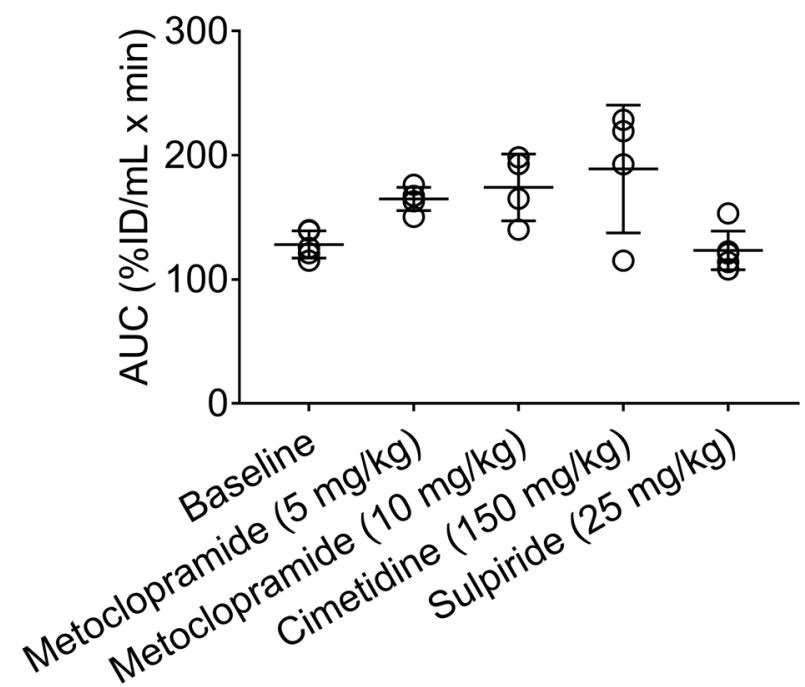

b

\section{$\mathrm{AUC}_{\text {brain }}$}

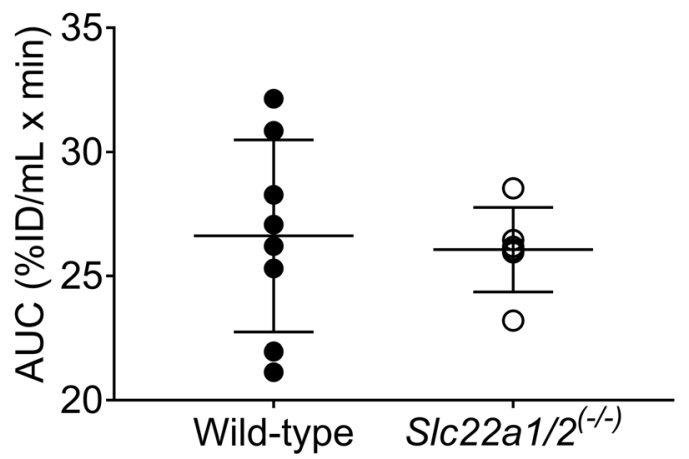

Fig. 9 (a) Area under the brain concentration-time curve of total radioactivity ( $A \cup C_{\text {brain, }} \% \mathrm{ID} / \mathrm{mL} \times \mathrm{min}$ ) in wild-type C57BL/6 mice without and with coadministration of metoclopramide (5 or $10 \mathrm{mg} / \mathrm{kg}$ ) or pretreatment with cimetidine ( $150 \mathrm{mg} / \mathrm{kg}$ ) or sulpiride $(25 \mathrm{mg} / \mathrm{kg})$. (b) $A \cup C_{\text {brain }}$ values in wildtype and SIc22al/2(-) FVB mice.

$\left[{ }^{11} \mathrm{C}\right]$ metoclopramide. In addition to its effect on kidney and liver uptake of $\left[{ }^{11} \mathrm{C}\right]$ metoclopramide, cimetidine pretreatment significantly decreased the urinary excretion of $\left[{ }^{11} \mathrm{C}\right]$ metoclopramide and its radiolabeled metabolites (Fig. $3 \mathrm{c}$ and $5 \mathrm{c}$ ), which pointed to an involvement of mouse MATEs. Since $\left[{ }^{11} \mathrm{C}\right]$ metoclopramide is also a substrate of $\mathrm{P}$ gp, this effect may also be attributed to an inhibition of P-gpmediated urinary excretion of radioactivity by cimetidine. However, although cimetidine is a substrate of $\mathrm{P}$-gp, it has not been classified as a P-gp inhibitor (37). To assess a possible role of P-gp in the urinary excretion of $\left[{ }^{11} \mathrm{C}\right]$ metoclopramide, it would be necessary to examine $A b c b 1 a / b^{(-)^{-)}}$mice. The second investigated cation transporter inhibitor was sulpiride, which has been shown to significantly inhibit OCT 1-mediated liver uptake of a PET microdose of $\left[{ }^{11} \mathrm{C}\right]$ sulpiride in humans at a single oral dose of approximately $8 \mathrm{mg} / \mathrm{kg}$ (32). 
Pretreatment of mice with sulpiride $(25 \mathrm{mg} / \mathrm{kg})$ tended to decrease the kidney/plasma and liver/plasma ratios of unchanged $\left[{ }^{11} \mathrm{C}\right]$ metoclopramide, but without reaching statistical significance. No effect of sulpiride on urinary excretion of radioactivity was observed.

We further observed that cimetidine dramatically increased the percentage of unchanged $\left[{ }^{1} \mathrm{C}\right]$ metoclopramide in each analyzed tissue and fluid (Table II). This suggests a reduction in the metabolism of $\left[{ }^{11} \mathrm{C}\right]$ metoclopramide, which can be most likely explained by the inhibition of metabolizing enzymes. Metoclopramide is mainly metabolized by CYP2D6, and to a lesser extent by CYP3A $(10,11)$. It has been estimated that $44 \%$ of total clearance of orally administered metoclopramide is accounted for by CYP2D6 metabolism in humans (38). Cimetidine is a potent CYP2D6 and CYP3A inhibitor (39), suggesting that the changes in $\left[{ }^{1} \mathrm{C}\right]$ metoclopramide metabolism after cimetidine administration can be explained by an inhibition of CYP2D6 and CYP3A activity. Moreover, inhibition of CYP2D6 might be the cause for the trend towards a decrease in $\left[{ }^{11} \mathrm{C}\right]$ metoclopramide metabolism observed after the coadministration of a pharmacological dose of unlabeled metoclopramide (Table II), as metoclopramide has been shown to be not only a substrate but also a potent inhibitor of CYP2D6 $(10,11)$.

In addition to the pretreatment with prototypical cation inhibitors, the effect of OCT1/2 on the kidney and liver uptake of $\left[{ }^{1} \mathrm{C}\right.$ ] metoclopramide was investigated by examining wild-type and Slc22a1/2 $2^{(-/-)}$mice (40). The uptake rate constants of total radioactivity from blood into the kidney $(k-$ uptake,kidney $)$ and from blood into liver $\left(k_{\text {uptake, liver }}\right)$ were significantly reduced in Slc22a1/2 $2^{(-/)}$mice as compared to wildtype mice (Fig. 7). Kidney/plasma and liver/plasma concentration ratios calculated at $15 \mathrm{~min}$ after radiotracer injection indicated that both renal and hepatic uptake were reduced in transporter knockout animals (Fig. 8). Similar effects have been shown for other known OCT1/2 substrates, such as metformin and sulpiride, for which a decrease in kidney/ plasma and liver/plasma concentration ratios was observed in Slc22a1/2 $2^{(-/)}$mice as compared to wild-type mice (31, $32,41)$. It is noteworthy that Slc22a1/2 knockout mice showed no increases in the plasma concentrations of $\left[{ }^{11} \mathrm{C}\right]$ metoclopramide, while cimetidine significantly increased the plasma concentration of $\left[{ }^{1} \mathrm{C}\right]$ metoclopramide (Fig. 4). This can be most likely explained by an additional inhibition of metabolic clearance of $\left[{ }^{11} \mathrm{C}\right]$ metoclopramide (i.e. metabolism and urinary excretion of radiolabeled metabolites) by cimetidine.

Our results suggest that the cation transporters OCT1/2 and MATEs were involved in the disposition of $\left[{ }^{11} \mathrm{C}\right]$ metoclopramide in mice. Changes in $\left[{ }^{1} \mathrm{C}\right]$ metoclopramide pharmacokinetics were moderate after Slc22al / 2 knockout, suggesting that renal and hepatic uptake by OGT $1 / 2$ are not the rate-limiting steps in $\left[{ }^{1 \mathrm{C}} \mathrm{C}\right]$ metoclopramide clearance in mice. A considerable part of the kidney and liver uptake of $\left[{ }^{1} \mathrm{C}\right]$ metoclopramide probably occurs via additional, unidentified uptake carriers and/or passive diffusion. This is supported by the results of Hendrickx et al. (24), who found that cellular uptake of metoclopramide in human OCT1 or OCT2 transfected cell lines was only $45 \%$ and $24 \%$ related to OCT 1 and OCT 2 activity, respectively. We were not able to separately assess the effect of MATE inhibition alone and inhibition of metabolism alone on $\left[{ }^{11} \mathrm{C}\right]$ metoclopramide disposition to elucidate which of these two processes was responsible for the rate-limiting steps in $\left[{ }^{11} \mathrm{C}\right]$ metoclopramide clearance. A previous study has shown that $\left[{ }^{11} \mathrm{C}\right]$ metoclopramide is metabolized to a considerably lower extent in humans than in mice (23). Approximately $65 \%$ of total radioactivity in human plasma was in the form of unchanged $\left[{ }^{11} \mathrm{C}\right.$ ] metoclopramide at $20 \mathrm{~min}$ after i.v. injection of a microdose of $\left[{ }^{11} \mathrm{C}\right]$ metoclopramide (23), while only $18 \%$ of total radioactivity in mouse plasma was in the form of unchanged $\left[{ }^{11} \mathrm{C}\right]$ metoclopramide at $15 \mathrm{~min}$ after injection in untreated wild-type mice (see Table II), which could mean that cation transporters may play a potentially greater role in the clearance of $\left[{ }^{11} \mathrm{C}\right]$ metoclopramide in humans than in mice.

Although caution is warranted when extrapolating rodent data to humans, our data suggest that alongside the saturation of metabolizing enzymes, saturation of OCT and MATE activity may at least partially contribute to the previously reported non-linearity in metoclopramide pharmacokinetics in rats and humans $(9,14,15,17)$. Moreover, our data suggest that metoclopramide may be a potential victim of metabolic or transport drug-drug interactions, although it should be noted that the investigated inhibitors were employed in the present work at far greater doses than those used in the clinic. Changes in enzyme or transporter activities caused by drugdrug interactions, disease or genetic polymorphisms may lead to changes in metoclopramide plasma pharmacokinetics, which may in turn affect the brain exposure to metoclopramide (Fig. 9) and thereby influence the occurrence and severity of its central side effects. This is supported by a previous study which established an association between polymorphisms in the CYP2D6 gene and the occurrence of central side effects of metoclopramide (6).

\section{CONCLUSION}

We were able to show that kidney and liver uptake of $\left[{ }^{1} \mathrm{C}\right]$ metoclopramide in mice is partially mediated by transport by OCT1 and OCT2, while MATE transporters contributed to the urinary excretion of $\left[{ }^{11} \mathrm{C}\right]$ metoclopramide and its radiolabeled metabolites. While transport by OCT1/2 was apparently not the rate-limiting step in $\left[{ }^{1} \mathrm{C}\right]$ metoclopramide 
clearance in mice, it cannot be ruled out that alterations in OCT1/2 and MATE activities, alongside the alterations in the activity of metabolizing enzymes, may also contribute to variability in metoclopramide plasma and tissue exposure and thereby cause variability in the side effects and clinical response to metoclopramide. Our study highlights the importance of considering the contribution of radiolabeled metabolites to the PET signal for assessing transporter effects in cases in which significant drug metabolism occurs over the duration of the PET scan. We provide a practical set-up in which the combination of PET imaging with metabolism experiments allows transporter effects to be differentiated from metabolism effects.

Acknowledgements and Disclosures. The authors wish to thank Mathilde Löbsch for help in conducting the PET experiments. This work was supported by the Austrian Science Fund (FWF) [grant KLI 694-B30, to O.L.].

\section{FUNDING}

Open Access funding provided by Medical University of Vienna.

Open Access This article is licensed under a Creative Commons Attribution 4.0 International License, which permits use, sharing, adaptation, distribution and reproduction in any medium or format, as long as you give appropriate credit to the original author(s) and the source, provide a link to the Creative Commons licence, and indicate if changes were made. The images or other third party material in this article are included in the article's Creative Commons licence, unless indicated otherwise in a credit line to the material. If material is not included in the article's Creative Commons licence and your intended use is not permitted by statutory regulation or exceeds the permitted use, you will need to obtain permission directly from the copyright holder. To view a copy of this licence, visit http://creativecommons.org/licenses/by/4.0/.

\section{REFERENCES}

1. Harrington RA, Hamilton CW, Brogden RN, Linkewich JA, Romankiewicz JA, Heel RC. Metoclopramide. An updated review of its pharmacological properties and clinical use. Drugs. 1983;25: 451-94.

2. US Food and Drug Administration. Reglan tablets (metoclopramide tablets, USP) safety information 2009. Available from: http://www.accessdata.fda.gov/drugsatfda_docs/label/2009/ 017854s052lbl.pdf.

3. Ganzini L, Casey DE, Hoffman WF, McCall AL. The prevalence of metoclopramide-induced tardive dyskinesia and acute extrapyramidal movement disorders. Arch Intern Med. 1993;153(12): 1469-75.
4. Shaffer D, Butterfield M, Pamer C, Mackey AC. Tardive dyskinesia risks and metoclopramide use before and after U.S. market withdrawal of cisapride. J Am Pharm Assoc (2003). 2004;44(6): 661-5.

5. Stapleton J, Wo JM. Current treatment of nausea and vomiting associated with gastroparesis: antiemetics, prokinetics, tricyclics. Gastrointest Endosc Clin N Am. 2009;19(1):57-72.

6. Parkman HP, Mishra A, Jacobs M, Pathikonda M, Sachdeva P, Gaughan J, et al. Clinical renponse and side effects of metoclopramide. J Clin Gastroenterol. 2012;46(6):494-503.

7. Bateman DN. Clinical pharmacokinetics of metoclopramide. Clin Pharmacokinet. 1983;8:523-9.

8. Teng L, Bruce RB, Dunning LK. Metoclopramide metabolism and determination by high-pressure liquid chromatography. J Pharm Sci. 1977;66(11):1615-8.

9. Bateman DN, Kahn C, Davies DS. The pharmacokinetics of metoclopramide in man with observations in the dog. Br J Clin Pharmacol. 1980;9:371-7.

10. Desta Z, Wu GM, Morocho AM, Flockhart DA. The gastroprokinetic and antiemetic drug metoclopramide is a substrate and inhibitor of cytochrome P450 2D6. Drug Metab Dispos. 2002;30:33643.

11. Livezey MR, Briggs ED, Bolles AK, Nagy LD, Fujiwara R, Furge LL. Metoclopramide is metabolized by CYP2D6 and is a reversible inhibitor, but not inactivator, of CYP2D6. Xenobiotica. 2014;44(4):309-19.

12. Argikar UA, Gomez J, Ung D, Parkman HP, Nagar S. Identification of novel metoclopramide metabolites in humans: in vitro and in vivo studies. Drug Metab Dispos. 2010;38(8): 1295-307.

13. Bauer M, Bamminger K, Pichler V, Weber M, Binder S, MaierSalamon A, et al. Impaired clearance from the brain increases the brain exposure to metoclopramide in elderly subjects. Clin Pharmacol Ther. 2020 Sep 23. https://doi.org/10.1002/cpt. 2052 Online ahead of print.

14. Graffner C, Lagerström PO, Lundborg P. Pharmacokinetics of metoclopramide intravenously and orally determined by liquid chromatography. Br J Clin Pharmacol. 1979;8:469-74.

15. Tam YK, Axelson JE, McErlane B, Ongley R, Price JDE. Dosedependent pharmacokinetics of metoclopramide in rat: an effect of hemoperfusion? J Pharmacol Exp Ther. 1981;217:764-9.

16. Kapil RP, Axelson JE, Ongley R, Price JDE. Nonlinear bioavailability of metoclopramide in the rat: evidence for saturable first-pass metabolism. J Pharm Sci. 1983;73(2):215-8.

17. Caillé F, Goutal S, Marie S, Auvity S, Cisternino S, Kuhnast B, et al. Positron emission tomography imaging reveals an importance of saturable liver uptake transport for the pharmacokinetics of metoclopramide. Contrast Media Mol Imaging. 2018;2018: 7310146.

18. Stosik AG, Junginger HE, Kopp S, Midha KK, Shah VP, Stavchansky S, et al. Biowaiver monographs for immediate release solid oral dosage forms: metoclopramide hydrochloride. J Pharm Sci. 2008;97(9):3700-8.

19. Doran A, Obach RS, Smith BJ, Hosea NA, Becker S, Callegari E, et al. The impact of P-glycoprotein on the disposition of drugs targeted for indications of the central nervous system: evaluation using the MDR1A/1B knockout mouse model. Drug Metab Dispos. 2005;33(1):165-74.

20. Nagaya Y, Nozaki Y, Kobayashi K, Takenaka O, Nakatani Y, Kusano K, et al. Utility of cerebrospinal fluid drug concentration as a surrogate for unbound brain concentration in nonhuman primates. Drug Metab Pharmacokinet. 2014;29(5):419-26.

21. Pottier G, Marie S, Goutal S, Auvity S, Peyronneau MA, Stute S, et al. Imaging the impact of the P-glycoprotein (ABCB 1) function on the brain kinetics of metoclopramide. J Nucl Med. 2016;57(2): 309-14. 
22. Auvity S, Caille F, Marie S, Wimberley G, Bauer M, Langer O, et al. P-glycoprotein (ABCB1) inhibits the influx and increases the efflux of ${ }^{11}$ C-metoclopramide across the blood-brain barrier: a PET study on nonhuman primates. J Nucl Med. 2018;59(10): 1609-15.

23. Tournier N, Bauer M, Pichler V, Nics L, Klebermass EM, Bamminger $\mathrm{K}$, et al. Impact of P-glycoprotein function on the brain kinetics of the weak substrate ${ }^{11} \mathrm{C}$-metoclopramide assessed with PET imaging in humans. J Nucl Med. 2019;60(7):985-91.

24. Hendrickx R, Johansson JG, Lohmann C, Jenvert RM, Blomgren A, Borjesson L, et al. Identification of novel substrates and structure-activity relationship of cellular uptake mediated by human organic cation transporters 1 and 2. J Med Chem. 2013;56(18):7232-42.

25. Giacomini K, Huang S, Tweedie D. Membrane transporters in drug development. Nat Rev Drug Discov. 2010;9(3):215-36.

26. Motohashi H, Inui K. Organic cation transporter OCTs (SLC22) and MATEs (SLC47) in the human kidney. AAPS J. 2013;15(2): 581-8.

27. Jonker JW, Wagenaar E, Mol CA, Buitelaar M, Koepsell H, Smit JW, et al. Reduced hepatic uptake and intestinal excretion of organic cations in mice with a targeted disruption of the organic cation transporter 1 (Octl [Slc22al]) gene. Mol Cell Biol. 2001;21(16):5471-7.

28. Omote H, Hiasa M, Matsumoto T, Otsuka M, Moriyama Y. The MATE proteins as fundamental transporters of metabolic and xenobiotic organic cations. Trends Pharmacol Sci. 2006;27(11):58793.

29. Nies AT, Koepsell H, Damme K, Schwab M. Organic cation transporters (OGTs, MATEs), in vitro and in vivo evidence for the importance in drug therapy. Fromm MF, Kim RB, editors. Drug transporters, Handbook of experimental pharmacology. Berlin Heidelberg: Springer-Verlag; 2011. p. 105-167.

30. Tournier N, Stieger B, Langer O. Imaging techniques to study drug transporter function in vivo. Pharmacol Ther. 2018;189:104-22.

31. Jensen JB, Sundelin EI, Jakobsen S, Gormsen LC, O.L. M, Frøkiaer J, et al. $\left[{ }^{11} \mathrm{C}\right]$-Labeled Metformin distribution in the liver and small intestine using dynamic positron emission tomography in mice demonstrates tissue-specific transporter dependency. Diabetes. 2016;65:1724-30.
32. Takano H, Ito S, Zhang X, Ito H, Zhang MR, Suzuki H, et al. Possible role of organic cation transporters in the distribution of $\left[{ }^{11} \mathrm{C}\right]$ sulpiride, a dopamine D2 receptor antagonist. J Pharm Sci. 2017;106(9):2558-65.

33. Loening AM, Gambhir SS. AMIDE: a free software tool for multimodality medical image analysis. Mol Imaging. 2003;2(3):131-7.

34. Shingaki T, Hume WE, Takashima T, Katayama Y, Okauchi T, Hayashinaka E, et al. Quantitative evaluation of mMatel function based on minimally invasive measurement of tissue concentration using PET with $\left[{ }^{1 \mathrm{l}} \mathrm{C}\right]$ metformin in mouse. Pharm Res. 2015;32(8): 2538-47.

35. Davies B, Morris T. Physiological parameters in laboratory animals and humans. Pharm Res. 1993;10(7):1093-5.

36. Ito S, Kusuhara H, Yokochi M, Toyoshima J, Inoue K, Yuasa H, et al. Competitive inhibition of the luminal efflux by multidrug and toxin extrusions, but not basolateral uptake by organic cation transporter 2, is the likely mechanism underlying the pharmacokinetic drug-drug interactions caused by cimetidine in the kidney. $\mathrm{J}$ Pharmacol Exp Ther. 2012;340(2):393-403.

37. Pan BF, Dutt A, Nelson JA. Enhanced transepithelial flux of cimetidine by Madin-Darby canine kidney cells overexpressing human pglycoprotein. J Pharmacol Exp Ther. 1994;270(1):1-7.

38. Tod M, Goutelle S, Clavel-Grabit F, Nicolas G, Charpiat B. Quantitative prediction of cytochrome P450 (CYP) 2D6mediated drug interactions. Clin Pharmacokinet. 201 1;50:519-30.

39. Martínez C, Albet C, Agúndez JA, Herrero E, Carrillo JA, Márquez M, et al. Comparative in vitro and in vivo inhibition of cytochrome P450 CP1A2, CYP2D6, and CYP3A by H2-receptor antagonists. Clin Pharmacol Ther. 1999;65(4):369-76.

40. JonkerJW, Wagenaar E, Van Eijl S, Schinkel AH. Deficiency in the organic cation transporters 1 and 2 (Oct1/Oct2 [Slc22al/ Slc22a2]) in mice abolishes renal secretion of organic cations. Mol Cell Biol. 2003;23(21):7902-8.

41. Higgins JW, Bedwell DW, Zamek-Gliszczynski MJ. Ablation of both organic cation transporter (OCT) 1 and OCT2 alters metformin pharmacokinetics but has no effect on tissue drug exposure and pharmacodynamics. Drug Metab Dispos. 2012;40(6):1170-7.

Publisher's Note Springer Nature remains neutral with regard to jurisdictional claims in published maps and institutional affiliations. 